\title{
The Effect of Land Cover Change on Soil Properties around Kibale National Park in South Western Uganda
}

\author{
J. G. M. Majaliwa, R. Twongyirwe, R. Nyenje, M. Oluka, B. Ongom, J. Sirike, D. Mfitumukiza, \\ E. Azanga, R. Natumanya, R. Mwerera, and B. Barasa
}

Institute of Environment and Natural Resources, Makerere University, P.O. Box 7062, Kampala, Uganda

Correspondence should be addressed to R. Twongyirwe, twongyirwe@gmail.com

Received 18 September 2009; Revised 5 March 2010; Accepted 19 April 2010

Academic Editor: Amaresh K. Nayak

Copyright (C) 2010 J. G. M. Majaliwa et al. This is an open access article distributed under the Creative Commons Attribution License, which permits unrestricted use, distribution, and reproduction in any medium, provided the original work is properly cited.

The change from natural forest cover to tea and Eucalyptus is rampant in protected areas of western Uganda. The objectives were; to examine the trend in land-use /cover change and determine the effect of these changes on the physico-chemical properties of soils around Kibale National Park. The trend in land use/cover change was assessed by analyzing a series of landsat images. Focused group discussions and key informant interviews were used for land-use/cover reconstruction. Three major land uses were included; woodlot (Eucalyptus grandis; 5 years old) ), tea (57 years old) and natural forest used as a control. Each of these land-uses were selected at two different North facing landscape positions and were replicated three times. A total of 36 composite soil samples were taken at $0-15$ and $15-30 \mathrm{~cm}$ depth from natural forest, Tea plantation and eucalyptus on three ridges. Results showed that small scale farming, tea and eucalyptus plantation and built up area have increased over time, to the expense of woodlot and forest cover. Tea and Eucalyptus have induced changes in: exchangeable $\mathrm{Mg}$ and $\mathrm{Ca}$, available $\mathrm{P}, \mathrm{SOM}, \mathrm{pH}$, and bulk density of sub soil $(P<.05)$. Landscape positions within land use also significantly influenced most soil properties $(P<.05)$. Similar findings were observed by Wang et al. (2006) in commercial tea plantations in China that received nitrogen fertilizers.

\section{Introduction}

Forest degradation in Uganda continues to be an issue of serious concern threatening to accelerate land degradation [1]. This forest loss has been mostly attributed to anthropogenic activities other than climatic forces [2]. Areas affected by the degradation include forests within and around Kibale National Park.

Kibale National Park is located in Western Uganda near the foothills of the Rwenzori Mountains and contains moist evergreen forest [3]. This natural forest is punctuated with patches of grassland which are mainly around the summits of the hill tops. Earlier, people within and around the forests coexisted sustainably and had access to the forest for basic needs such as water, firewood, vegetables, honey, and medicine for domestic use [4]. However, in the 1970s and 1980s the forest experienced serious degradation mainly due to anthropogenic activities. Despite the forest providing important social and environmental benefits, it is increasingly threatened by accelerating rates of forest conversion and degradation [5]. As the area experiences crop destruction due to wild animal raids especially elephants, people have resorted to tree plantation establishment notably, eucalyptus and pines [6]. Gradually these plantations have expanded horizontally forming new major vegetation covers.

Land use practices affect the distribution and supply of soil nutrients by directly altering soil properties and by influencing biological transformations in the rooting zone [7]. For instance, cultivation of forests diminishes the soil carbon (C) within a few years of initial conversion [7] and substantially lowers mineralisable of Nitrogen $(\mathrm{N})$ [8]. The conversion of forest to crop land has been associated with reduction in organic matter content of the top soil $[9,10]$ and subsequently, decline in productivity, since organic matter content is responsible for the productivity in soils $[11,12]$. Islam and Weil [13] reported an increase in bulk density and a reduction in porosity and aggregate stability following the 


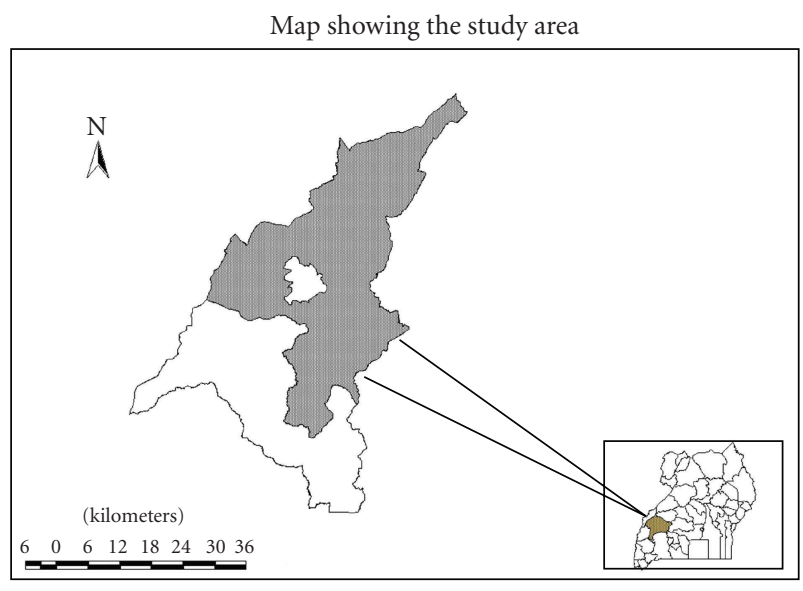

圆 Bunyanganbu sub-county

Burahya sub-county

Figure 1: Bunyanganbu and Burahya sub-counties in Fort Portal district in Uganda.

conversion of forest land to crop land. Similar findings were reported by Motavalli and McConnell [14] and Riezebos and Loerts [15]. Such changes in soil properties predispose the soil to soil erosion, a major soil degradation process in Uganda [16]. This study was therefore carried out to determine the trend in land use/cover change and assess how these trends have impacted the soil properties in and around Kibale National Park.

\section{Materials and Methods}

2.1. Description of the Study Area. The study was undertaken in Burahya county in Kabarole district (Uganda). The area is located between latitude $0^{\circ} 13^{\prime}-0^{\circ} 41^{\prime} \mathrm{N}$ and longitude $30^{\circ}$ $19^{\prime}-30^{\circ} 32^{\prime} \mathrm{E}$ in Western Uganda near the foothills of the Rwenzori Mountains and covers approximately $10.16 \mathrm{~km}^{2}$. It lies between $1390 \mathrm{~m}$ and $1625 \mathrm{~m}$ above sea level. Currently, moist evergreen forest, tea plantation, small-scale agriculture, and woodland plantations are the dominant land use/cover in the area $[3,17]$. The national park consists of mature, mid-altitude, moist semideciduous and evergreen forest $(57 \%)$, grassland (15\%), woodland (4\%), lakes and wetlands $(2 \%)$, colonizing forest (19\%), and plantations of exotic trees (1\%) primarily Cupressus lusitanica, Pinus patula, P. caribaea, and Eucalyptus species, [3]. The soil is classified as Lixic Ferralsols. The area receives bimodal rainfall occurring from March to May and from September to November. The mean annual rainfall in the region is $1750 \mathrm{~mm}$ whereas the mean daily minimum and maximum temperatures are $15.5^{\circ} \mathrm{C}$ and $23.7^{\circ} \mathrm{C}$, respectively.

\subsection{Research Approach}

2.2.1. Trends in Land Use/Cover Change. Land use/cover change trends in the area were determined by analyzing series of satellite images (landsat images) of 1974 and 2000 covering the study area. In addition, the land use/cover map of 1986 was obtained from the National Biomass Study [18]. In Addition, a land use map of the two subcounties was clipped from the USGS (2005) land use/cover map of Africa. The major land use /cover classes included natural forest, grassland, small-scale cultivation and largescale agriculture and woodland. Large scale agriculture was mainly Tea plantations; while woodland mainly consisted of eucalyptus in the study area. Preliminary maps were produced using Integrated Land and Water Information System (ILWIS version 3.1). The 1974 land use/cover of the area was reconstructed using targeted interviews. The preliminary map produced from the analysed landsat image of 2000 and field observations were used to update the USGS (2005) map of the study area and generate a land use/cover map of the year 2009.

2.2.2. Effect of Land Use Change on Soil Properties. For selection of the sampling sites, two transects of $5 \mathrm{~km}$ cutting across the dominant land use/cover were drawn in Arc View 3.1. A reconnaissance was carried out in the field and three major land uses were selected based on their history, occurrence at different landscape positions, and possibility of having a minimum of three replications. The selected sampling sites were those originally under forest and have been converted to the current land use/cover. Two land uses satisfied the set criteria namely, woodlot (Eucalyptus grandis; 5 years old) and tea (57 years old). The natural forest was used as a control. Each of these land uses was selected at two different North facing landscape positions (Back slope, foot slope) [19] and were replicated three times.

For each replicate, a composite sample was obtained from three different points at two depths $0-15 \mathrm{~cm}$ and $15-$ $30 \mathrm{~cm}$. The soil depth of $0-30 \mathrm{~cm}$ was chosen because it is the agricultural layer [20]. Soil core samples were also taken one from each depth $(0-15$ and $15-30 \mathrm{~cm})$ for determination of bulk density and hydraulic conductivity using the core method and falling head method, respectively [21]. Soil samples were air-dried and analyzed for $\mathrm{pH}$, organic matter (SOM), total $\mathrm{N}$, available $\mathrm{P}$, exchangeable bases ( $\mathrm{Ca}, \mathrm{Mg}$, and K) following standard methods [22]. Soil pH was measured using $\mathrm{pH}$ a meter (1:2.5 soil: water); SOM and total $\mathrm{N}$ were determined using Walkley and Black method and Kjedhal method, respectively. Soil texture was determined using Bouyoucos hydrometer method [23] and their textural classes according to the FAO classification [24].

2.3. Statistical Analysis. The trend in each of the land use/cover was estimated using regression techniques. Separation of means was done in Genstat Discovery version using the LSD. Values of soil properties that differed at $P \leq .05$ were considered significant trends.

\section{Results}

3.1. Land Use/Cover Change Maps in 1973, 1986, and 2009. Figure 2 and Table 1 show the land use/cover for three time series. Generally small-scale farming, tea plantation, 

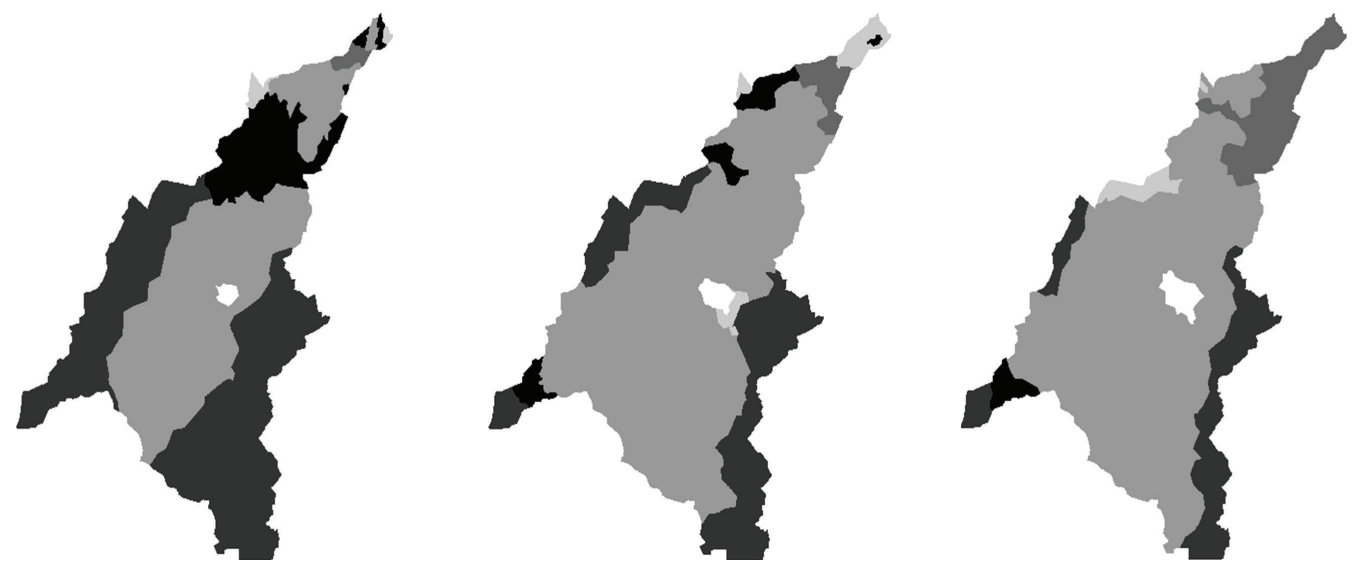

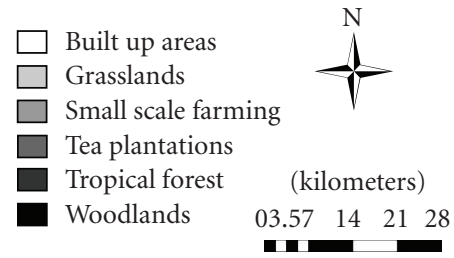

(a)

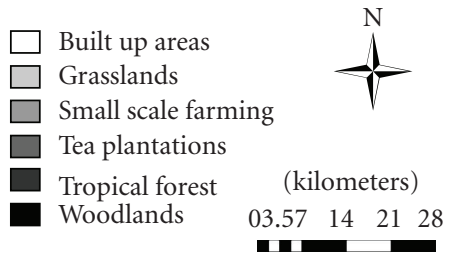

(b)

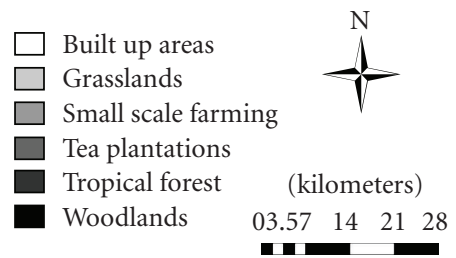

(c)

Figure 2: land use/cover for three time series, 1973, 1987, 2009.

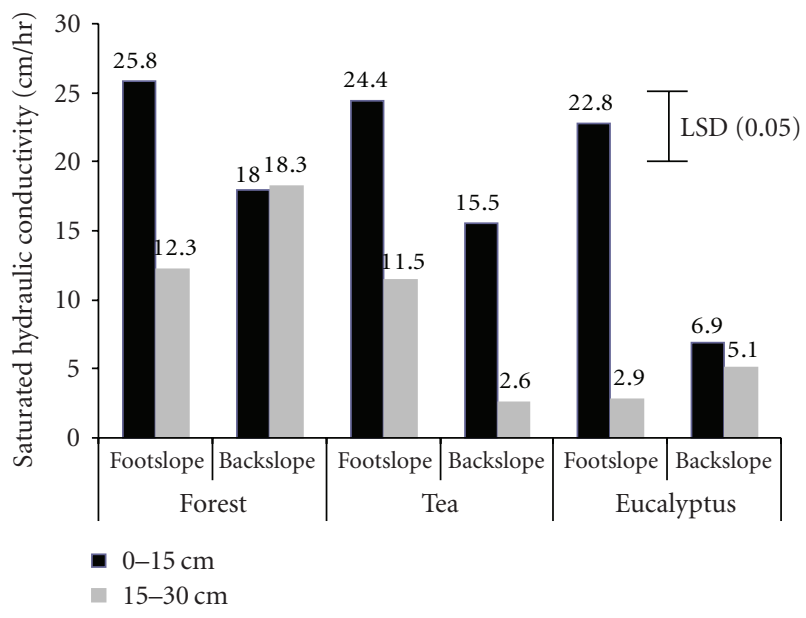

FIgURE 3: Interaction effect of landscape position and depth on saturated hydraulic conductivity in the different land uses.

and built up area have increased over time, and woodlot has decreased with time. Previous studies have shown this continuing trend [25].

From the figures above, the highest percentage of land in 1973 was tropical forest $(45 \%)$ compared to small-scale farming in 1987 (69\%) and 2009 (71.4\%). The smallest percentage of land in $1973(0.5 \%)$ was built up areas compared to tea plantations and grasslands in $1987(3 \%)$ and 2009 (1.9\%), respectively. The changes in land use could be attributed to agricultural expansion that took place in the areas adjacent to Kibale National Park [25] as well as an increase in energy demand (firewood). Such expansion was associated with arrival of new immigrants into the areas.

3.1.1. Effect of Land Use on Selected Soil Properties. Soil physical and chemical properties in natural forests, tea plantations, and Eucalyptus plantations are presented in Tables 2 and 3 for soil depths $0-15 \mathrm{~cm}$ and $15-30 \mathrm{~cm}$, respectively. Top soil $(0-15 \mathrm{~cm})$ properties except total $\mathrm{N}$, exchangeable potassium, and sodium differed significantly $(P$ $<.05)$ across the land uses. Textural analysis indicates that the fraction of clay highly significantly $(P<.001)$ differed between LUs. Clay contents were higher in Eucalyptus than in tea plantations and natural forests. Bulk density was lower in the forest compared to Eucalyptus and Tea. Soil pH (mean $=3.53 \pm 0.41$ ) in tea plantations was statistically lower than in natural forests and in Eucalyptus plantations, respectively. Similarly, mean values of SOM were statistically higher in the respective LUs. Total $\mathrm{N}$ in natural forests and Eucalyptus were roughly equal. Available phosphorus in natural forests was about 6 and 3 times lower than in tea plantations and in Eucalyptus plantations, respectively. The highest level of exchangeable $\mathrm{Mg}$ was observed in natural forest followed by Eucalyptus plantations and tea plantations, respectively.

Likewise, soil properties in the lower depths $(15-30 \mathrm{~cm})$ differed significantly $(P<.05)$ across the land uses. The properties that were similar were clay and silt fractions, composition, total N, SOM, exchangeable sodium, fraction of clay and silt. Comparing soil properties across the LUs, $\mathrm{pH}$, available $\mathrm{P}$ and bulk density differed considerably. For instance, soil $\mathrm{pH}$ in tea plantations and saturated hydraulic conductivity in natural forests were much lower and higher, respectively than in the other two LUs. As for the top soil 
TABLE 1: showing land use and cover changes.

\begin{tabular}{|c|c|c|c|c|c|c|}
\hline & 1973 & $\%$ & 1987 & $\%$ & 2009 & $\%$ \\
\hline Built up areas & 9 & 0.5 & 18 & 1 & 28 & 1.5 \\
\hline Grasslands & 15 & 1 & 49 & 3 & 36 & 1.9 \\
\hline Small-scale farming & 760 & 41 & 1259 & 69 & 1308 & 71.4 \\
\hline Tea plantations & 15 & 1 & 48 & 3 & 178 & 9.7 \\
\hline Tropical forest & 828 & 45 & 385 & 21 & 254 & 13.8 \\
\hline Woodlands & 207 & 11 & 74 & 4 & 29 & 1.6 \\
\hline
\end{tabular}

TABLE 2: Mean \pm SD of selected soil $(0-15 \mathrm{~cm})$ physical and chemical properties in the three land uses.

\begin{tabular}{|c|c|c|c|c|}
\hline \multirow{2}{*}{ Soil properties } & \multicolumn{3}{|c|}{ Land use/cover } & \multirow{2}{*}{$P<.05$} \\
\hline & Natural forest & Tea & Eucalyptus & \\
\hline $\mathrm{pH}$ & $4.72 \pm 0.55^{\mathrm{a}}$ & $3.53 \pm 0.41^{\mathrm{b}}$ & $5.13 \pm 0.61^{\mathrm{c}}$ & $<.001$ \\
\hline $\operatorname{SOM}(\%)$ & $6.48 \pm 0.56^{\mathrm{a}}$ & $7.20 \pm 1.15^{\mathrm{b}}$ & $4.97 \pm 0.45^{\mathrm{c}}$ & .002 \\
\hline Total N (\%) & $0.26 \pm 0.07$ & $0.31 \pm 0.05$ & $0.24 \pm 0.04$ & Ns \\
\hline Av. P (ppm) & $3.32 \pm 0.99^{\mathrm{a}}$ & $20.50 \pm 9.52^{b}$ & $11.30 \pm 10.03^{\mathrm{a}}$ & .004 \\
\hline $\mathrm{Ca}(\operatorname{cmol}(\mathrm{p}+) / \mathrm{kg})$ & $9.70 \pm 4.18^{\mathrm{a}}$ & $2.30 \pm 1.90^{\mathrm{b}}$ & $9.30 \pm 5.20^{\mathrm{a}}$ & .010 \\
\hline $\operatorname{Mg}(\operatorname{cmol}(\mathrm{p}+) / \mathrm{kg})$ & $2.26 \pm 0.80^{\mathrm{a}}$ & $0.66 \pm 0.74^{\mathrm{b}}$ & $2.00 \pm 0.55^{\mathrm{a}}$ & $<.001$ \\
\hline $\mathrm{K}(\mathrm{cmol}(\mathrm{p}+) / \mathrm{kg})$ & $0.21 \pm 0.15$ & $0.29 \pm 0.19$ & $0.34 \pm 0.20$ & Ns \\
\hline $\mathrm{Na}(\mathrm{cmol}(\mathrm{p}+) / \mathrm{Kg})$ & $0.04 \pm 0.01$ & $0.05 \pm 0.01$ & $0.04 \pm 0.01$ & Ns \\
\hline Bulk density $\left(\mathrm{g} / \mathrm{cm}^{3}\right)$ & $0.72 \pm 0.05^{\mathrm{a}}$ & $1.18 \pm 0.08^{b}$ & $1.22 \pm 0.08^{b}$ & .018 \\
\hline Ksat $(\mathrm{cm} / \mathrm{hr})$ & $21.90 \pm 24.35$ & $19.03 \pm 14.78$ & $14.86 \pm 17.84$ & Ns \\
\hline Clay (\%) & $15.67 \pm 4.46^{\mathrm{a}}$ & $23.33 \pm 7.55^{\mathrm{b}}$ & $36.00 \pm 3.35^{c}$ & $<.001$ \\
\hline Silt (\%) & $13.67 \pm 2.94$ & $13.00 \pm 3.03$ & $16.00 \pm 2.53$ & Ns \\
\hline Textural class & Sandy Loam & Sandy clay Loam & Sandy Clay & \\
\hline
\end{tabular}

Values followed by the same letters in a row are not significantly different at $P<.05$; n.s.: not significant.

$(0-15 \mathrm{~cm})$, bulk density was lower in the forest compared to Eucalyptus and Tea.

\subsubsection{Interactions Between Land Use and Landscape Positions} on Selected Properties in the Top and Subsoil Layers. Within land uses, only soil $\mathrm{pH}$ and exchangeable $\mathrm{Mg}$ in the top soil depth differed significantly with landscape positions $(P$ $<.05)$. Soil $\mathrm{pH}(P=.014)$ and exchangeable $\mathrm{Mg}(P=.033)$ were significantly lower in the back slope than foot slope positions. Nonetheless, the other properties particularly SOM (6.08 versus 6.35), available P (15.8 versus 7.6), K (0.33 versus 0.22 ), and saturated hydraulic conductivity though not significant were lower in the respective slope positions (Table 4 and Figure 3, resp.).

Significant interactions between land use and landscape positions in the lower soil depth were observed for $\mathrm{Ca}(P$ $=.016)$ and exchangeable $\operatorname{Mg}(P=.036)$. The mean values of the two parameters in the back slope were lower than in the foot slope positions within a land use.

In addition, Magnesium, Calcium, and Phosphorus were significantly different at the different landscape positions $(P$ $<.05)$. Also, clay content was significant at the two depths $(P<.05)$ with depth $15-30 \mathrm{~cm}$ generally having higher clay content. Eucalyptus had the highest clay content in both depths although depth $15-30 \mathrm{~cm}$ had a slightly lower content than $0-15 \mathrm{~cm}$.

\section{Discussion}

Although mean soil $\mathrm{pH}$ in all the LUs is lower than the critical value of 5.5 [26], soils from only tea plantations are strongly acidic, $\mathrm{pH}$ less than 4.5 [27]. The lowest $\mathrm{pH}$, though corresponds to high SOM contents in the latter LU, could partly be attributed to the long-term effect of fertilizer application as it was also observed in analogous; total $\mathrm{N}$ in tea plantations was much above the critical value of $0.2 \%$. Similar findings were observed by Wang et al. [28] in commercial tea plantations in China that received mostly nitrogen fertilizers.

Soil organic matter in all the LUs is well above $3.0 \%$ cited by Okalebo et al. [22] as the critical value. The observed differences in SOM seem to relate to the level of input of organic materials which was higher (thickness of debris/litter was qualitatively higher) in tea plantations than natural forests. Residues from regular pruning and leaf fall were common in tea plantations and combined with application of inorganic fertilizer-enhanced decomposition and mineralization of plant residues compared to natural conditions [29]. Arguably, OM turnover is higher in tea plantations than in natural forests. Consequently, available $\mathrm{P}$ was in only tea plantations higher than the critical of $15 \mathrm{ppm}$ [22]. According to Brady [27], the bulk of phosphorus exists in organic form and P is very stable [30] in the soil, thus a good indicator of organic matter accumulation and quality; 
TABLE 3: Mean \pm SD of selected soil $(15-30 \mathrm{~cm})$ physical and chemical properties in the three land use/covers.

\begin{tabular}{|c|c|c|c|c|}
\hline Soil properties & Natural forest & Tea & Eucalyptus & $P<.05$ \\
\hline$\overline{\mathrm{pH}}$ & $4.70 \pm 0.69^{\mathrm{a}}$ & $3.72 \pm 0.24^{\mathrm{b}}$ & $4.88 \pm 0.85^{\mathrm{a}}$ & 0.018 \\
\hline SOM (\%) & $5.92 \pm 0.84$ & $6.14 \pm 1.49$ & $5.26 \pm 1.95$ & Ns \\
\hline Total Nitrogen (\%) & $0.26 \pm 0.06$ & $0.26 \pm 0.04$ & $0.26 \pm 0.08$ & Ns \\
\hline Av. P (ppm) & $3.32 \pm 0.99^{\mathrm{a}}$ & $19.40 \pm 10.04^{\mathrm{b}}$ & $12.00 \pm 8.70^{c}$ & .002 \\
\hline $\mathrm{Ca}(\operatorname{cmol}(\mathrm{p}+) / \mathrm{kg})$ & $7.63 \pm 2.87^{\mathrm{a}}$ & $3.55 \pm 1.98^{\mathrm{b}}$ & $5.66 \pm 2.97^{\mathrm{a}}$ & .014 \\
\hline $\operatorname{Mg}(\operatorname{cmol}(\mathrm{p}+) / \mathrm{kg})$ & $2.20 \pm 0.38^{\mathrm{a}}$ & $1.01 \pm 0.46^{\mathrm{b}}$ & $1.57 \pm 0.59^{c}$ & $<.001$ \\
\hline $\mathrm{K}(\mathrm{cmol}(\mathrm{p}+) / \mathrm{kg})$ & $0.14 \pm 0.03$ & $0.22 \pm 0.10$ & $0.33 \pm 0.17$ & Ns \\
\hline $\mathrm{Na}(\operatorname{cmol}(\mathrm{p}+) / \mathrm{kg})$ & $0.042 \pm 0.02$ & $0.04 \pm 0.01$ & $0.12 \pm 0.19$ & Ns \\
\hline Bulk density $\left(\mathrm{g} / \mathrm{cm}^{3}\right)$ & $0.84 \pm 0.03^{\mathrm{a}}$ & $1.48 \pm 0.15^{\mathrm{b}}$ & $1.40 \pm 0.09^{\mathrm{b}}$ & .05 \\
\hline Ksat $(\mathrm{cm} / \mathrm{h})$ & $15.27 \pm 12.38$ & $7.00 \pm 12.24$ & $3.99 \pm 3.21$ & Ns \\
\hline Clay $(\%)$ & $23.33 \pm 6.53$ & $27.00 \pm 7.67$ & $31.00 \pm 7.56$ & Ns \\
\hline Silt (\%) & $15.00 \pm 1.67^{\mathrm{a}}$ & $16.67 \pm 7.12^{\mathrm{a}}$ & $24.67 \pm 10.25^{\mathrm{b}}$ & Ns \\
\hline Textural class & Sandy clay loam & Sandy clay loam & Sandy clay loam & \\
\hline
\end{tabular}

Values followed by the same letters in a row are not significantly different at $P<.05$; n.s.: not significant.

TABLE 4: Effect of land use/cover change on selected physicochemical properties.

\begin{tabular}{|c|c|c|c|c|c|c|c|c|c|c|c|c|c|}
\hline Depth $(\mathrm{cm})$ & Land use & Landscape position & \multicolumn{4}{|c|}{$\%$} & $\begin{array}{l}\text { Av.P } \\
\text { ppm }\end{array}$ & $\begin{array}{c}\mathrm{BD} \\
\mathrm{Mg} / \mathrm{m}^{3}\end{array}$ & \multicolumn{4}{|c|}{$\mathrm{Cmol}(\mathrm{p}+) / \mathrm{kg}$} & $\mathrm{pH}$ \\
\hline \multirow{6}{*}{$0-15$} & Forest & Back slope & 14.67 & 12.67 & 6.42 & 0.27 & 3.70 & 1.69 & 6.43 & 0.26 & 1.67 & 0.05 & 4.30 \\
\hline & & Foot slope & 16.67 & 14.67 & 6.54 & 0.24 & 3.00 & 1.65 & 12.97 & 0.16 & 2.85 & 0.04 & 5.13 \\
\hline & Tea & Back slope & 17.33 & 14.00 & 7.07 & 0.29 & 28.10 & 1.55 & 1.23 & 0.40 & 0.34 & 0.05 & 3.30 \\
\hline & & Foot slope & 29.33 & 12.00 & 7.33 & 0.32 & 12.90 & 1.39 & 3.37 & 0.18 & 0.99 & 0.04 & 3.77 \\
\hline & Eucalyptus & Back slope & 34.67 & 16.00 & 4.75 & 0.25 & 15.50 & 1.53 & 11.53 & 0.34 & 2.32 & 0.04 & 5.53 \\
\hline & & Foot slope & 37.33 & 16.00 & 5.19 & 0.22 & 7.00 & 1.26 & 7.13 & 0.34 & 1.68 & 0.05 & 4.73 \\
\hline \multirow{6}{*}{$15-30 \mathrm{~cm}$} & Forest & Back slope & 19.33 & 14.00 & 5.96 & 0.30 & 2.90 & 1.36 & 6.00 & 0.12 & 2.24 & 0.03 & 4.30 \\
\hline & & Foot slope & 27.33 & 16.00 & 5.89 & 0.23 & 3.70 & 1.52 & 9.27 & 0.16 & 2.16 & 0.05 & 5.10 \\
\hline & Tea & Back slope & 24.00 & 13.33 & 6.62 & 0.26 & 26.60 & 1.19 & 3.77 & 0.28 & 0.90 & 0.04 & 3.63 \\
\hline & & Foot slope & 30.00 & 20.00 & 5.66 & 0.25 & 12.20 & 1.17 & 3.33 & 0.16 & 1.13 & 0.04 & 3.80 \\
\hline & Eucalyptus & Back slope & 30.00 & 25.33 & 5.81 & 0.25 & 16.60 & 1.27 & 7.90 & 0.32 & 2.06 & 0.04 & 5.37 \\
\hline & & Foot slope & 32.00 & 24.00 & 4.71 & 0.27 & 7.40 & 1.17 & 3.20 & 0.33 & 1.08 & 0.20 & 4.40 \\
\hline Land use $\left(\mathrm{LSD}_{0.05}\right)$ & & & 5.00 & 4.95 & 1.08 & ns & 5.31 & 0.15 & 2.41 & ns & 0.43 & ns & 0.41 \\
\hline Landscape $\left(\mathrm{LSD}_{0.05}\right)$ & & & 4.08 & ns & ns & ns & 4.33 & ns & ns & ns & ns & ns & ns \\
\hline Depth $\left(\mathrm{LSD}_{0.05}\right)$ & & & ns & 4.04 & ns & ns & ns & 0.12 & ns & ns & ns & ns & ns \\
\hline Land use* $\mathrm{LP}\left(\mathrm{LSD}_{0.05}\right)$ & & & ns & ns & ns & ns & 7.51 & ns & 3.40 & ns & 0.60 & ns & 0.58 \\
\hline
\end{tabular}

Exchangeable Ca was below the critical value of $4.0 \%$ only in tea plantations. Except in natural forests, the mean value of exchangeable $\mathrm{Mg}$ in other land uses is slightly below the critical values of $0.5 \mathrm{cmol}(\mathrm{p}+) / \mathrm{kg}$.

Interpretations of values of hydraulic conductivity with ranges established by Landon [26] indicate that water flow in soils of all the LUs is rapid (Ksat $>15 \mathrm{~cm} / \mathrm{hr}$ ). According to Lichner et al. [31], roots can affect saturated hydraulic conductivity in topsoil directly by inducing the preferred flow through macro-pores or indirectly by their influence on soil structure. Soil texture under the three different land use covers was dominantly sandy-soil type which is characterized by high-saturated hydraulic conductivity.

The lower values of soil properties in back slope than foot slope within land uses could be related to deposition of eroded materials which occurs in the latter landscape
[19]. Steeper landscapes are generally more prone to detachment/loss of soil materials by water erosion [32].

\section{Conclusions}

Small-scale farming, tea and eucalyptus plantation, and built up area have increased over time, at the expense of the woodlot and forest cover.

The change from natural forest cover to tea and Eucalyptus induced changes in top soil properties namely, exchangeable $\mathrm{Mg}$ and $\mathrm{Ca}$, available $\mathrm{P}, \mathrm{SOM}, \mathrm{pH}$, and bulk density of sub soil. Landscape positions within land use also significantly influenced most of the soil properties denoting interactions. There is a need therefore of assessing the spatiotemporal consequence of these changes at watershed 
level, carrying out an economic analysis of these activities at household level, and identifying the most beneficial Kibale National Park trees for afforestation.

\section{Acknowledgments}

The authors are grateful to Makerere University Institute of Environment and Natural Resources, its Director, and entire staff, and to Mac-Arthur foundation for having supported and funded this Research.

\section{References}

[1] A. Y. Banana and W. Gombya-Ssembajjwe, "Successful forest management: the importance of security of tenure and rule enforcement in Ugandan forests," in People and Forests: Communities, Institutions, and Governance, C. Gibson, M. A. McKean, and E. Ostrom, Eds., pp. 87-98, MIT Press, Cambridge, Mass, USA, 2000.

[2] E. Matthews, R. Payne, M. Rohweder, and S. Murrat, "Pilot analysis of global Legacies of agriculture," 2000.

[3] C. A. Chapman and J. E. Lambert, "Habitat alteration and the conservation of African primates: case study of Kibale National Park, Uganda," American Journal of Primatology, vol. 50, no. 3, pp. 169-185, 2000.

[4] Forest Act, Laws of Uganda Chapters $2 \& 6$, Government of Uganda, 1964.

[5] S. Brown and A. E. Lugo, "Effects of forest clearing and succession on the carbon and nitrogen content of soils in Puerto Rico and US Virgin Islands," Plant and Soil, vol. 124, no. 1 , pp. 53-64, 1990.

[6] L. Naughton-Treves, "Predicting patterns of crop damage by wildlife around Kibale National Park, Uganda," Conservation Biology, vol. 12, no. 1, pp. 156-168, 1998.

[7] D. Murty, M. U. F. Kirschbaum, R. E. Mcmurtrie, and H. Mcgilvray, "Does conversion of forest to agricultural land change soil carbon and nitrogen? A review of the literature," Global Change Biology, vol. 8, no. 2, pp. 105-123, 2002.

[8] D. D. Richter, D. Markewitz, P. R. Heine et al., "Legacies of agriculture and forest regrowth in the nitrogen of old-field soils," Forest Ecology and Management, vol. 138, no. 1-3, pp. 233-248, 2000.

[9] S. M. Ross, "Organic matter in tropical soils: current conditions, concerns and prospects for conservation," Progress in Physical Geography, vol. 17, no. 3, pp. 265-305, 1993.

[10] S. Singh and J. S. Singh, "Water-stable aggregates and associated organic matter in forest, savanna, and cropland soils of a seasonally dry tropical region, India," Biology and Fertility of Soils, vol. 22, no. 1-2, pp. 76-82, 1996.

[11] P. A. Sanchez, K. D. Shepherd, M. J. Soule, et al., "Soil fertility replenishment in Africa: an investment in natural capital," in Replenishing Soil Fertility in Africa, R. J. Buresh, P. A. Sanchez, and F. Calhoun, Eds., vol. 51, pp. 1-46, Soil Science Society of America, Madison, Wis, USA, 1997.

[12] C. A. Palm, C. N. Gachengo, R. J. Delve, G. Cadisch, and K. E. Giller, "Organic inputs for soil fertility management in tropical agroecosystems: application of an organic resource database," Agriculture, Ecosystems and Environment, vol. 83, no. 1-2, pp. 27-42, 2001.

[13] K. R. Islam and R. R. Weil, "Land use effects on soil quality in a tropical forest ecosystem of Bangladesh," Agriculture, Ecosystems and Environment, vol. 79, no. 1, pp. 9-16, 2000.
[14] P. P. Motavalli and J. McConnell, "Land use and soil nitrogen status in a tropical Pacific island environment," Journal of Environmental Quality, vol. 27, no. 1, pp. 119-123, 1998.

[15] H. T. Riezebos and A. C. Loerts, "Influence of land use change and tillage practice on soil organic matter in southern Brazil and eastern Paraguay," Soil and Tillage Research, vol. 49, no. 3 , pp. 271-275, 1998.

[16] J. Tukahirwa, "Land Use Change-Associated Deterioration in Soil Quality in Uganda: a case study from Sango Bay, Lake Mburo National Park Area and Kabale/Ntungamo Districts Border Area," The Landuse Change, Impacts and Dynamics Project Working Paper 41, 2003.

[17] C. A. Chapman, S. R. Balcomb, T. R. Gillespie, J. P. Skorupa, and T. T. Struhsaker, "Long-term effects of logging on African primate communities: a 28-year comparison from Kibale National Park, Uganda," Conservation Biology, vol. 14, no. 1, pp. 207-217, 2000.

[18] National Biomass study, Uganda: Land Cover Stratification (Vegetation), Uganda Forest Department, Kampala, Uganda, 1996.

[19] C.-C. Tsui, Z.-S. Chen, and C.-F. Hsieh, "Relationships between soil properties and slope position in a lowland rain forest of southern Taiwan," Geoderma, vol. 123, no. 1-2, pp. 131-142, 2004.

[20] M. M. Tenywa, "Agricultural potential in the Rwenzori Mountains; special reference to the lower slopes in Bwamba," in The Rwenzori Mountains National Park, Uganda, H. Osmaston, J. Tukahirwa, C. Basalirwa, and J. Nyakaana, Eds., pp. 180-189, Fountain, Kampala, Uganda, 1998.

[21] A. Klute and C. Dirksen, "Hydraulic conductivity and diffusivity: laboratory methods," in Methods of Soil Analysis-Part 1: Physical and Mineralogical Methods, A. Klute, Ed., pp. 687734, American Society of Agronomy and Soil Science Society of America, Madison, Wis, USA, 1986.

[22] J. R. Okalebo, K. W. Gathua, and P. L. Woomer, Laboratory Methods of Soil and Plant Analysis: A Working Manual, Sacred African Publishers, Nairobi, Kenya, 2nd edition, 2002.

[23] G. J. Bouyoucos, "Hydrometer method improved for making particle size analysis of soils," Agronomy Journal, vol. 53, pp. 464-465, 1962.

[24] FAO, "Soil units of the soil Map of the World," FAO-UNESCOISRIC, Rome, Italy, 1990.

[25] S. Mugisha, "Root causes of land cover/use change in Uganda; an account for the past 100 years. Land Use Change Impacts and Dynamics (LUCID)," Project Working Paper 14, International Livestock Research Institute, Nairobi, Kenya, 2002.

[26] J. R. Landon, A Handbook for Soil Survey and Agricultural Evaluation in the Tropics and Subtropics, Longman, Harlow, UK, 1991.

[27] N. Brady, The Nature and Properties of Soils, Macmillan, New York, NY, USA, 13th edition, 1990.

[28] R. Wang, X. Shi, Y. Wei, X. Yang, and J. Uoti, "Yield and quality responses of citrus (Citrus reticulate) and tea (Podocarpus fleuryi Hickel.) to compound fertilizers.", Journal of Zhejiang University Science, vol. 7, no. 9, pp. 696-701, 2006.

[29] I. Trinsoutrot, S. Recous, B. Bentz, M. Linères, D. Chèneby, and B. Nicolardot, "Biochemical quality of crop residues and carbon nijtrogen mineralizaion Kineics under non-limiting nitrogen conditions," Soil Science Society of American Journal, vol. 64, pp. 918-926, 2002.

[30] I. C. R. Holford, "Soil phosphorus: its measurement, and its uptake by plants," Australian Journal of Soil Research, vol. 35, no. 2, pp. 227-239, 1997. 
[31] L. Lichner, J. Majercak, S. Slabon, and V. Stekauerova, Prenos Rozpustenych Latok v Pode, Veda, Bratislava, Slovakia, 1994.

[32] A. Lufafa, M. M. Tenywa, M. Isabirye, M. J. G. Majaliwa, and P. L. Woomer, "Prediction of soil erosion in a Lake Victoria basin catchment using a GIS-based Universal Soil Loss model," Agricultural Systems, vol. 76, no. 3, pp. 883-894, 2003. 

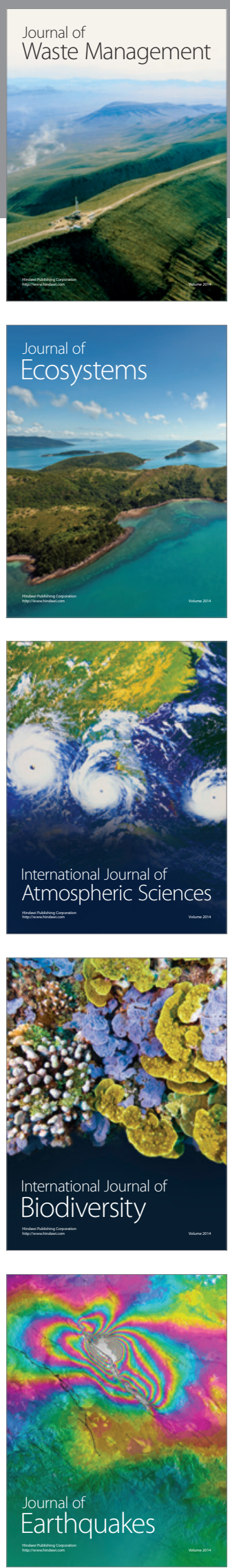
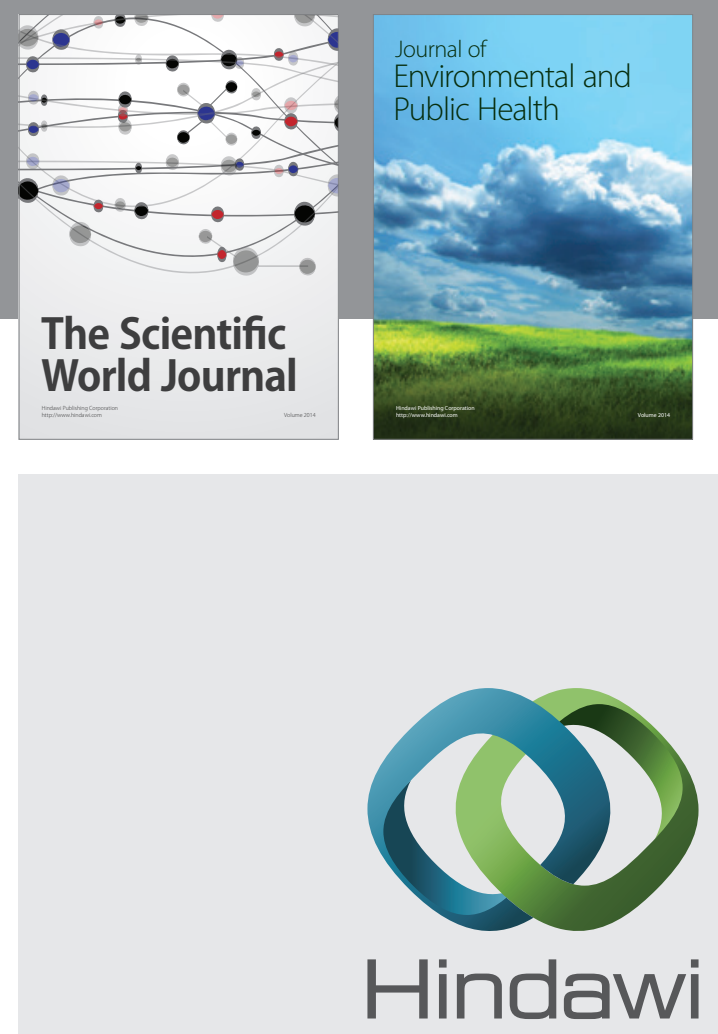

Submit your manuscripts at

http://www.hindawi.com
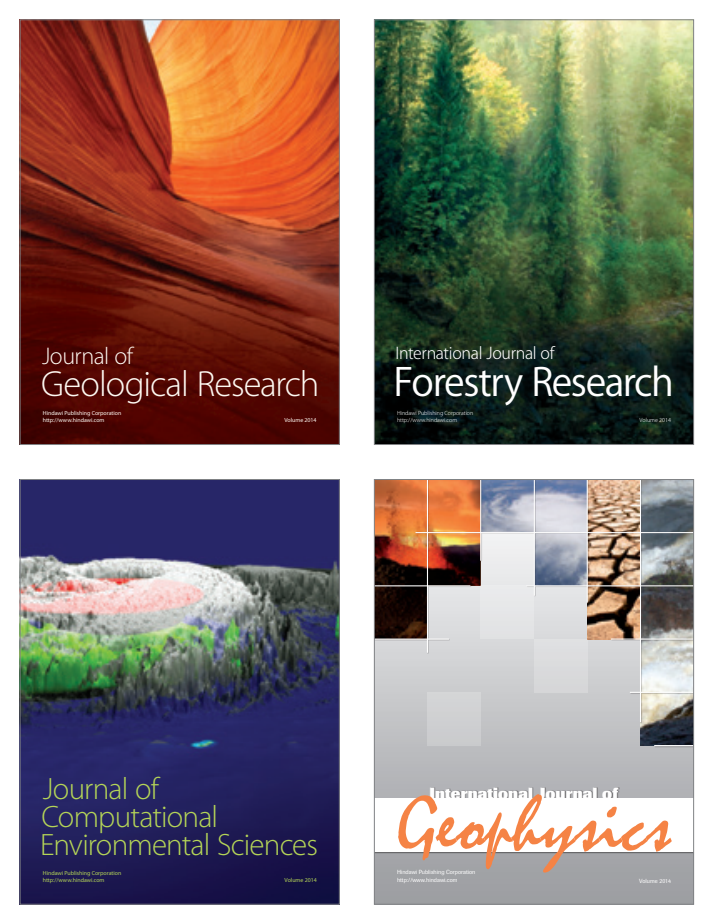
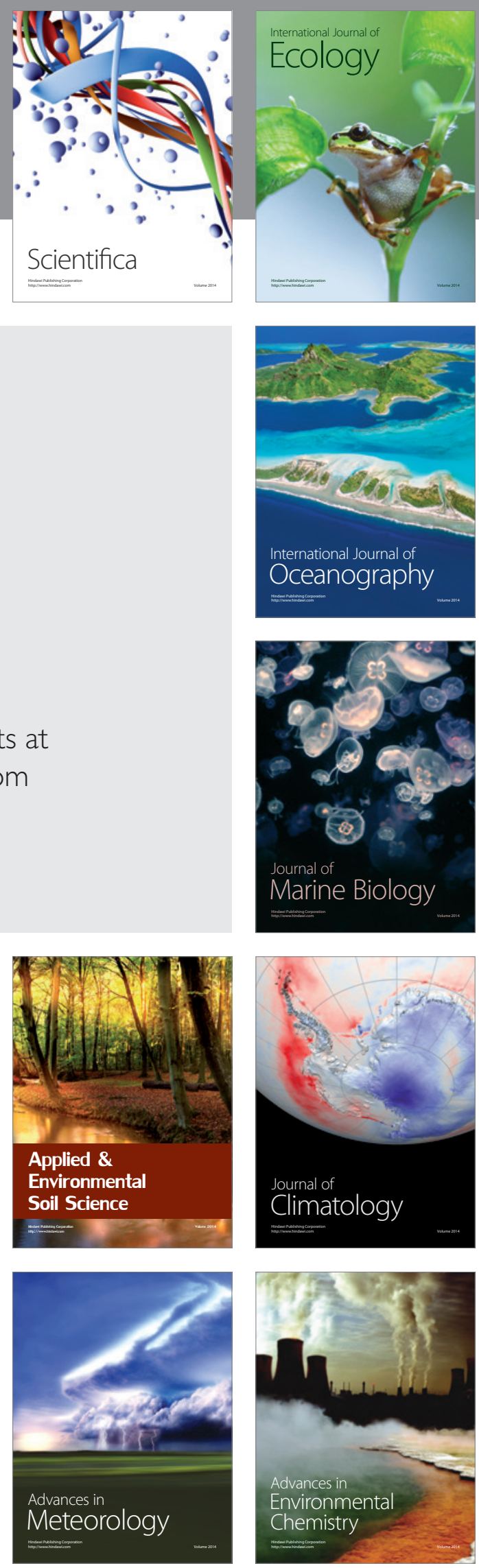